\title{
Lipides alimentaires et métabolisme du tissu adipeux chez les ruminants, les porcs et les rongeurs *
}

\author{
Y Chilliard
}

INRA, laboratoire Sous-nutrition des ruminants, Theix, 63122 Saint-Genès-Champanelle, France

Cette revue bibliographique traite des effets de la supplémentation en lipides des rations pour vaches laitières sur l'efficacité énergétique, la production et la composition du lait, le bilan énergique et les variations de poids vif et de note d'état corporel. Les lipides alimentaires ne modifient pas les variations de poids ou de note d'état corporel après le pic de lactation, mais tendent à accroître la perte de poids vif en début de lactation, bien qu'ils accroissent simultanément le bilan énergétique calculé des vaches, et tendent à accroître le dépôt des lipides corporels chez les bovins en croissance. Les lipides alimentaires diminuent la synthèse de novo d'acides gras dans le tissu adipeux, sans changer l'activité de la lipoprotéine-lipase ni l'estérification totale des acides gras. La libération basale d'acides gras par le tissu adipeux in vitro, ainsi que les réponses lipolytiques bêta-adrénergiques, sont accrues par les acides gras polyinsaturés distribués sous forme protégée.

La supplémentation en lipides accroît les lipides corporels chez le porc en croissance élevé dans un environnement thermique neutre ou chaud, mais pas dans un environnement froid.
La supplémentation lipidique accroît l'ingestion d'énergie et la sécrétion des lipides du lait, et diminue la perte de poids vif chez la truie en lactation. Les lipides alimentaires diminuent la synthèse de novo d'acides gras et la libération basale de glycérol par le tissu adipeux, et tendent à accroître les réponses lipolytiques bêta-adrénergétiques simultanément à un accroissement de la fluidité membranaire et à une diminution de l'activité de la phosphodiestérase.

Les lipides alimentaires accroissent les lipides corporels chez les rongeurs de laboratoire. Les acides gras polyinsaturés sont toutefois moins efficaces que les acides gras saturés, avec des variations selon les essais. L'activité lipoprotéine-lipasique du tissu adipeux est généralement diminuée. La synthèse d'acides gras par le foie est fortement diminuée par les acides gras polyinsaturés, alors que la réponse est moins marquée dans le tissu adipeux. La réponse lipolytique bêta-adrénergique du tissu adipeux est diminuée, et l'estérification des acides gras est accrue, en particulier par les acides gras saturés, qui tendent aussi à induire une résistance à l'insuline.

\footnotetext{
* Ce thème a fait l'objet d'une revue bibliographique parue dans J Dairy Sci (1993) 76, 3897-3931.
} 